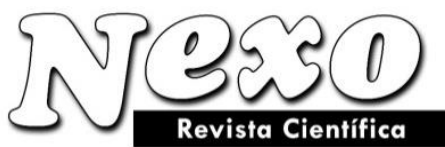

Vol. 34, No. 01, pp. 379-389/Marzo 2021

\title{
Correlation analysis of the parameters of oats assimilation apparatus and productivity elements
}

\section{Análisis de correlación de los parámetros de los aparatos de asimilación de avena y elementos de productividad}

\author{
Galina A. Batalova*, Evgeny M. Lisitsyn \\ N.V. Rudnitsky Federal Agrarian Scientific Center of the Northeast. \\ Kirov, Russian Federation \\ *g.batalova@mail.ru
}

(recibido/received: 20-November-2020; aceptado/accepted: 05-January-2021)

\begin{abstract}
On sod-podzolic soils, new data is obtained on the functioning of the photosynthetic structures of oat leaves in various climatic conditions and of biomass accumulation (plant productivity). Based on threeyear data (2015-2017) of field experiments with 29 oat genotypes, the relationship between the development of productivity elements and the characteristics of the plant assimilation apparatus is analyzed. The pigment content (chlorophyll a, chlorophyll b, carotenoids) was evaluated in acetone extracts on a UVmini-1240 spectrophotometer (SHIMADZU Corporation, Japan). Statistically significant correlations were established between the total leaf surface area and grain mass per plant $(r=0.664)$, the number of spikelets in a panicle, grain mass per panicle and the mass of the panicle itself $(r=0.548 \ldots$ 0.613). These correlations decreased during a drought and increased in conditions of excessive moisture. Oat genotypes with a larger sub-flag leaf had a larger panicle, with a large number of spikelets, grains and of larger grain mass per panicle and plant. During a drought, these correlations decreased. The correlation of the flag leaf area with the grain mass of the panicle and plant under stressful conditions of excessive moisture or a drought increased. With excessive moisture, an increase in the proportion of chlorophyll a in the total chlorophyll pool and in the composition of the reaction centers of photosystems was observed in genotypes with an increased number of spikelets and grains in a panicle, with larger grain masses per panicle and plant, and a mass of 1000 grains. During a drought, the correlation of the content of chlorophylls $\mathrm{a}$ and $\mathrm{b}$ increased with the following signs: panicle length, panicle mass, number of spikelets in a panicle, and number of grains in a panicle. However, an increase in panicle mass and the number of grains in it was accompanied by a decrease in the proportion of chlorophyll a in the total pigment pool and in the composition of reaction centers.
\end{abstract}

Keywords: Carotenoids; Chlorophyll; Flag leaf; Leaf area; Panicle.

\section{RESUMEN}

Aquí se considera un flujo de datos nuevos obtenidos en suelos de césped y podzol sobre el funcionamiento de la estructura de hojas de avena en varias condiciones climáticas y sobre la acumulación de biomasa (productividad de plantas). Los datos sobre las pruebas de campo con 29 genotipos de avena conducidas en 2015-17 se usan para analizar la conexión entre el desarrollo de los elementos de 
productividad y las características del mecanismo asimilador de la planta. Se evaluó el contenido de la clorofila $a$ y $b$ y de los carotenoides en extracto de acetona en un espectrofotometro japonés SHIMADZU Uvmini-1240. Se identificaban las correlaciones estadísticamente significativas entre el área total de la superficie de hojas y la masa de granos de una planta $(r=0.664)$ y también entre la cantidad de espigas en una panoja y su masa $(r=0.548 \ldots 0.613)$. Se bajaban las correlaciones en caso de aridez y aumentaban en caso de humectación excesiva. Los genotipos del avena con hojas debajo de bandera más grandes tenían una panoja más grande, con muchas espigas, granos y una masa más alta de granos por espiga y por planta. Las correlaciones se bajaban en caso de aridez. En caso de humectación excesiva o aridez estresadora se aumentaba la correlación entre el área de la hoja bandera y la masa de los grano por espiga. En caso de humectación excesiva se registraba el aumento del contenido del clorofila $a$ en el fondo general de clorofilas y en los centros de reacción de los fotosistemas para genotipos con una alta cantidad de espigas y granos por panoja, una masa más alta de granos por panoja y planta y una masa más alta de 1000 granos. En condiciones áridas se acrecentaba la correlación entre el contenido de las clorofilas $a$ y $b$ y tales caracterísicas como el largo de panoja, la masa panoja, el número de espigas por panoja. Con todo eso, el aumento de la masa de panoja y de la cantidad de granos en esa fue acompañada por el abajamiento de la fracción del clorofila $a$ en en el rango total de los pigmentos y en los centro de reacción.

Palabras claves: Carotenoides; Clorofila; Hoja bandera; Área de hoja; Panoja.

\section{INTRODUCTION}

Photosynthesis is the only source of the formation of plastic substances that are used to build a plant organism. The efficiency of the photosynthetic apparatus depends on the development of the pigment complex of the leaves and the assimilation surface of the plant, especially after the earing phase (Xie et al., 2011). Breeders strive to increase the productivity of newly created varieties; however, the main attention is paid to the development of plant structural elements, and the functional parameters of the assimilation apparatus are rarely included in the model of a grain crops variety (Batalova, 2013; Schennikova, 2015; Nava et al., 2016). This is mainly because it is not yet possible to reveal a clear connection between the value of the obtained crop and the development of the leaf surface and the pigment complex. At the same time, certain scientists underline the necessity to take into account the parameters physiologically related to production (leaf area, chlorophyll content, leaf life, etc.) when selecting high-yielding oat genotypes (Hisir et al., 2012).

The two top leaves make the largest contribution to the formation of the grain yield (Mistra, 1986; Rahman et al., 2014); therefore, researchers choose the area indices of these leaves (which are actively functioning during the filling period) as a criterion for assessing plant productivity (Verma et al., 2016). The larger the leaf area, the greater the expected rate of organic matter accumulation, especially grain. The contribution of the flag leaf area is determined by the increased chlorophyll content (Santosh, 2011). In the work by Al-Tahir (2014), a significant correlation was found between oat grain yield and leaf area $(\mathrm{r}=$ $0.806)$ and total chlorophyll content $(r=0.739)$. The authors suggest using these indicators as selection criteria to improve oats productivity.

Plant leaves pigments (chlorophylls, carotenoids, etc.) play a crucial role in plant development by participating in photosynthesis reactions (Croft and Chen, 2017). Chlorophyll is responsible for capturing photons of light by light-collecting complexes of photosystems, transferring their energy and separation of charges in reaction centers (Chen, 2014). In this regard, new methods are being constantly developed and modernized to assess the content and functioning of photosynthetic pigments in plant leaves (Sytar et al., 2015) under normal and stressful growth conditions (Chen et al., 2016; Khan et al., 2018).

There is evidence in the scientific literature that oats genotypes (Avena sativa L.) which have significantly higher total dry mass per shoot in the flowering phase, were characterized by higher dry leaf mass on the shoot, wet and dry flag leaf mass, flag leaf area and its chlorophyll b content (Kakad et al., 2017). At the 
same time, the chlorophyll content had a high heritability coefficient in the broad sense: $\mathrm{h} 2$ values for the total chlorophyll content in the flag leaf were 94\% (chlorophyll b-97\%, chlorophyll a-92\%); the level of chlorophyll b was controlled by the additive effect of genes, which allowed the authors to speak about the suitability of this indicator for direct selection by phenotype to improve the parameter.

The relationship between the leaf surface index (LAI) and grain yield per plant was statistically high (0.756) in experiments (Mushtaq et al., 2013). The correlation of the chlorophyll content with the grain yield per plant was slightly lower $(0.446)$, but it was twice as high as the degree of correlation with the green mass yield (0.244). The high chlorophyll content in oats leaves can also be associated with resistance to abiotic factors of the growth environment (Xie et al., 2011).

Based on the three-year data (2015-2017) of field experiments with 29 samples (varieties and breeding lines) of oats, the present research establishes the interdependence of the development of individual productivity elements and the assimilation apparatus characteristics of oat plants in case of instable agroclimatic resources during the growth season; these allow obtaining new synthetic forms of oats for the selection of adaptive genotypes that ensure stable plant productivity regardless of environmental limits.

\section{MATERIALS AND METHODS}

A series of field experiments in 2015-2017 (the experimental field of the Federal Center for North-East Studies) analysed 29 varieties and breeding lines of oats created in the North-Eastern Federal University; the names of the samples are given in the Tables. Plants were grown in accordance with the 'Methodology of state testing of crops varieties' (1985).

The hydrothermal conditions of vegetation periods varied significantly in different years of the study. In 2015 , sufficient hydration and elevated temperature were noted (HTC $=1.34$, normal vegetation conditions). The average yield per variety was $3.3 \mathrm{t} / \mathrm{ha}$. In 2016, in the period from germination to flowering (critical for oats in terms of moisture consumption) a drought of medium intensity was noted $(\mathrm{SCC}=0.62)$. As a result, a sharp decrease in the average yield to $1.8 \mathrm{t} / \mathrm{ha}$ was observed. The growth season of 2017 was characterized by excessive moisture and a lack of the sum of effective temperatures $(\mathrm{HTC}=2.27)$, but the average yield remained at the level of $2015(3.4 \mathrm{t} / \mathrm{ha})$.

For a qualitative and quantitative analysis of the pigment composition on 29 individual plants of four replicates of each genotype, the total leaf area and the area of the flag and sub-flag leaves in the flowering phase were evaluated. The repetition of field assessments is fourfold. The pigment content (chlorophyll a, chlorophyll b, carotenoids) was estimated using a UVmini-1240 spectrophotometer (SHIMADZU Corporation, Japan). The selection of pigments and the calculation of their content were carried out according to (Lichtenthaler \& Bushmann, 2001) in acetone extracts (100\% acetone).

The obtained data were processed statistically using the Microsoft Office Excel 2007 and StatSoft Statistica 11 software packages. Since the study discusses mainly the correlation dependencies between the parameters, the tables show only arithmetic mean values without indicating an average error or standard deviation.

\section{RESULTS AND DISCUSSION}

Despite significant differences in the hydrothermal conditions of the vegetation periods of 2015-2017, the variation coefficient of the average indicators of oats productivity elements ranged from 10.4 (panicle length) to $18.5 \%$ (grain weight per plant) (Table 1). 
Table 1. Average indicators of the development of oats productivity elements in the conditions of Kirov Oblast, 2015-2017

\begin{tabular}{|c|c|c|c|c|c|c|c|c|}
\hline Variety, line & $\begin{array}{c}\text { Plant } \\
\text { height, } \\
\mathrm{cm}\end{array}$ & $\begin{array}{l}\text { Panicle } \\
\text { length, } \\
\mathrm{cm}\end{array}$ & $\begin{array}{l}\text { Panicle } \\
\text { weight, } \\
\text { g }\end{array}$ & $\begin{array}{c}\text { Number } \\
\text { of } \\
\text { spikelets } \\
\text { per } \\
\text { panicle, } \\
\text { pcs } \\
\end{array}$ & $\begin{array}{l}\text { Number } \\
\text { of grains } \\
\text { per } \\
\text { panicle, } \\
\text { pcs }\end{array}$ & $\begin{array}{c}\text { mass of } \\
\text { grain per } \\
\text { panicle, } \\
\text { g }\end{array}$ & $\begin{array}{l}\text { Mass of } \\
\text { grain } \\
\text { per } \\
\text { plant, g }\end{array}$ & $\begin{array}{c}\text { Mass of } \\
1000 \\
\text { grains, } g\end{array}$ \\
\hline $14 \mathrm{~h} 12 \mathrm{o}$ & 85.5 & 17.7 & 2.5 & 22.0 & 50.6 & 1.4 & 1.5 & 29.5 \\
\hline $168 \mathrm{~h} 10$ & 87.7 & 16.4 & 2.4 & 27.5 & 45.7 & 1.8 & 2.6 & 39.3 \\
\hline $1 \mathrm{~h} 07$ & 89.6 & 18.6 & 2.5 & 20.4 & 46.8 & 1.4 & 1.6 & 28.8 \\
\hline $2 \mathrm{~h} 09$ & 83.4 & 17.2 & 2.3 & 28.4 & 39.4 & 1.5 & 1.8 & 38.2 \\
\hline 378h08 & 84.0 & 16.6 & 2.2 & 23.5 & 38.8 & 1.7 & 2.0 & 44.5 \\
\hline 397h07 & 77.6 & 10.2 & 2.1 & 25.1 & 41.6 & 1.6 & 1.8 & 39.6 \\
\hline $3 \mathrm{~h} 14$ & 87.4 & 15.5 & 2.1 & 26.8 & 46.8 & 1.7 & 1.8 & 36.0 \\
\hline 629h09 & 88.1 & 18.2 & 2.5 & 24.7 & 52.7 & 1.4 & 1.4 & 26.4 \\
\hline $683 \mathrm{~h} 05$ & 80.2 & 17.0 & 2.4 & 25.1 & 46.9 & 1.4 & 1.7 & 32.5 \\
\hline $7 \mathrm{~h} 12 \mathrm{o}$ & 88.3 & 18.3 & 2.9 & 23.5 & 53.3 & 1.5 & 1.9 & 29.4 \\
\hline $857 \mathrm{~h} 05$ & 79.5 & 16.8 & 2.7 & 25.9 & 43.0 & 1.3 & 1.4 & 31.5 \\
\hline SW BETANIA & 82.3 & 16.2 & 2.5 & 23.6 & 42.9 & 1.8 & 2.4 & 42.9 \\
\hline Zvolen & 78.1 & 15.0 & 2.2 & 24.0 & 39.4 & 1.7 & 1.9 & 42.9 \\
\hline Altair & 92.2 & 16.5 & 2.4 & 23.2 & 36.0 & 1.6 & 1.9 & 46.2 \\
\hline Ant & 81.7 & 14.8 & 1.8 & 20.8 & 37.0 & 1.4 & 1.6 & 38.9 \\
\hline Argamak & 80.6 & 15.2 & 2.1 & 27.0 & 41.5 & 1.5 & 1.8 & 36.3 \\
\hline AC-7 & 80.6 & 15.5 & 2.0 & 22.3 & 38.5 & 1.7 & 1.9 & 44.7 \\
\hline Begunok & 81.5 & 15.4 & 2.2 & 22.0 & 40.2 & 1.7 & 2.2 & 42.7 \\
\hline Bulany & 90.7 & 17.7 & 1.6 & 21.6 & 34.7 & 1.3 & 1.5 & 37.4 \\
\hline Vyatsky & 87.6 & 16.8 & 2.0 & 20.4 & 41.4 & 1.2 & 1.3 & 29.8 \\
\hline I-4584 & 88.0 & 16.4 & 2.5 & 26.7 & 48.8 & 1.8 & 2.0 & 37.3 \\
\hline I-4592 & 86.8 & 15.1 & 2.4 & 29.7 & 60.6 & 2.1 & 2.4 & 35.2 \\
\hline I-4595 & 85.5 & 16.7 & 2.1 & 25.6 & 47.9 & 1.8 & 2.0 & 37.2 \\
\hline I-4618 & 89.7 & 17.6 & 2.8 & 27.2 & 46.1 & 1.9 & 2.3 & 41.9 \\
\hline Korifey & 94.0 & 19.0 & 2.6 & 28.9 & 49.3 & 2.1 & 2.2 & 43.7 \\
\hline Lev & 86.8 & 16.6 & 2.3 & 23.3 & 43.4 & 1.8 & 1.9 & 41.6 \\
\hline Lgovsky 72 & 96.0 & 19.1 & 2.7 & 27.1 & 49.7 & 2.1 & 2.4 & 42.3 \\
\hline Pirouette & 91.3 & 17.3 & 2.4 & 26.5 & 52.1 & 2.0 & 2.2 & 38.0 \\
\hline Yakov & 88.4 & 17.5 & 2.6 & 24.6 & 52.5 & 2.2 & 2.4 & 42.5 \\
\hline
\end{tabular}

The correlation analysis showed that, in general, over 3 years in the entire set of studied varieties, the taller samples differed in the larger total area of the leaf apparatus (Table 2) and, in particular, the sub-flag leaf area (pair correlation coefficients, statistically significant at $\mathrm{p} \leq 0.05$ amounted to 0.560 and 0.512 , respectively). 
Table 2. Average indicators of the leaf surface development in oats samples in the conditions of Kirov Oblast, 20152017

\begin{tabular}{|c|c|c|c|}
\hline Variety, line & Flag leaf area, $\mathrm{cm}^{2}$ & Sub-flag leaf area, $\mathrm{cm}^{2}$ & Total leaf area per plant, $\mathrm{cm}^{2}$ \\
\hline $14 \mathrm{~h} 12 \mathrm{o}$ & 15.48 & 22.00 & 57.14 \\
\hline $168 \mathrm{~h} 10$ & 16.84 & 26.31 & 79.97 \\
\hline $1 \mathrm{~h} 07$ & 13.57 & 19.76 & 52.10 \\
\hline $2 \mathrm{~h} 09$ & 17.50 & 22.91 & 67.28 \\
\hline 378h08 & 14.81 & 20.53 & 57.74 \\
\hline 397h07 & 13.59 & 19.90 & 53.72 \\
\hline $3 \mathrm{~h} 14$ & 10.43 & 20.68 & 65.19 \\
\hline 629 h09 & 15.96 & 21.87 & 55.11 \\
\hline $683 \mathrm{~h} 05$ & 14.65 & 19.50 & 53.77 \\
\hline $7 \mathrm{~h} 12 \mathrm{o}$ & 16.64 & 23.46 & 66.72 \\
\hline $857 \mathrm{~h} 05$ & 16.40 & 18.90 & 53.72 \\
\hline $\begin{array}{l}\text { SW } \\
\text { BETANIA }\end{array}$ & 16.48 & 20.91 & 66.34 \\
\hline Zvolen & 15.01 & 17.62 & 49.26 \\
\hline Altair & 13.53 & 17.15 & 57.67 \\
\hline Ant & 11.27 & 16.99 & 49.74 \\
\hline Argamak & 14.16 & 21.10 & 59.66 \\
\hline $\mathrm{AC}-7$ & 12.29 & 16.21 & 48.14 \\
\hline Begunok & 15.18 & 18.80 & 56.25 \\
\hline Bulany & 11.01 & 19.21 & 56.68 \\
\hline Vyatsky & 12.71 & 18.63 & 48.34 \\
\hline I-4584 & 13.80 & 22.77 & 59.89 \\
\hline I-4592 & 11.77 & 19.75 & 57.81 \\
\hline I-4595 & 11.66 & 18.84 & 51.19 \\
\hline I-4618 & 17.82 & 26.09 & 72.74 \\
\hline Korifey & 16.75 & 24.50 & 76.07 \\
\hline Lev & 14.30 & 20.12 & 57.85 \\
\hline Lgovsky 72 & 16.95 & 27.56 & 79.57 \\
\hline Pirouette & 13.95 & 19.74 & 62.05 \\
\hline Yakov & 14.40 & 21.65 & 63.64 \\
\hline
\end{tabular}

Relatively low values of pair correlations are explained by the strong influence of growth conditions: while under normal moisture conditions, the correlation coefficients were highly significant (for the total leaf area of 0.802 and the sub-leaf area of 0.729), in conditions of excess moisture in 2017, the coefficients decreased markedly ( 0.643 and 0.650 , respectively), and in the conditions of dry 2016, there was no significant relationship in the level of character variation between different types of oats.

In the whole set of varieties, the total leaf surface area was most correlated with such productivity element as grain weight per plant $(\mathrm{r}=0.664)$. A statistically significant relationship was noted between the total leaf area development and the number of spikelets per panicle (0.613), grain weight per panicle $(0.564)$ and the mass of the panicle itself (0.548). Samples with a larger assimilation apparatus area also had longer panicles $(r=0.395)$. The relationship between the leaf apparatus development and such 
productivity elements as the number of spikelets per panicle, grain weight per panicle and grain mass per plant was statistically significant in all the years of research, changing only in quantitative terms. In the conditions of the 2016 drought, the correlation coefficients were the smallest $(0.413 ; 0.472$ and 0.419 , respectively), and in the conditions of excessive moistening in 2017 , they were the largest $(0.845 ; 0.735$ and 0.782 , respectively).

Since for the formation of the reproductive organs of crops, the two upper leaves of the plant (flag and sub-flag) are of greatest importance, the relationships between the development of these leaves and the elements of panicle productivity were analyzed.

As the correlation analysis showed, in the studied set of varieties, samples with a larger sub-flag leaf were characterized by a larger panicle (statistically significant correlations with panicle length and mass: 0.444 and 0.629$)$, with a large number of spikelets $(\mathrm{r}=0.558)$, grains $(0.448)$, and grain mass from panicles and plants (0.413 and 0.463). Under the normal moisture conditions in 2015, such regularities intensified, with the exception of grain weight per plant $(r=0.622 ; 0.811 ; 0.720 ; 0.650 ; 0.566$ and 0.640 , respectively). With the onset of arid conditions, the relationship with the number of grains per panicle became statistically insignificant, other correlations decreased quantitatively to the level of $0.438 \ldots 0.515$. Excessive humidity in 2017 led to a significant increase in the studied interdependencies (up to $0.647 \ldots$ 0.870), but the varieties with different areas of the sub-flag leaf did not differ statistically by panicle length.

The relationship between the productivity elements development of the panicle and the flag leaf qualitatively and quantitatively differed from the patterns identified for the sub-flag leaf. Thus, on average over three years, only two pair correlation coefficients were statistically significant: panicle length $(\mathrm{r}=$ $0.382)$ and panicle mass $(r=0.722)$. The reason for this lies in the significant difference in the years of research in terms of the moisture content of the growth season.

In the analysis of individual years of the study, a statistically significant relationship with panicle length was noted only under normal growth conditions $(r=0.699)$, while in conditions of a drought or excessive humidity, inter-varietal differences in the flag leaf area did not affect this indicator. At the same time, in arid growth conditions with a decrease in the relationship with panicle mass (up to 0.537), an increase in the flag leaf area was accompanied by a statistically significant increase in grain mass per panicle $(\mathrm{r}=$ $0.371)$ and per plant $(\mathrm{r}=0.415)$.

Excessive humidity contributed to the fact that samples with a larger flag leaf area had a more developed panicle $(r=0.848)$ with a large number of spikelets $(r=0.722)$, grains $(r=0.485)$, and grain weight per panicle and plant $(\mathrm{r}=0.547$ and 0.582$)$. In case of normal humidity, these relationships either intensified (for number of grains per panicle to 0.571), or, conversely, decreased (panicle mass up to 0.759; number of spikelets per panicle up to 0.700 ; grain weight per panicle up to 0.398 ).

Since the formation of plastic substances used to construct both vegetative and reproductive organs occurs in the chloroplasts of green parts of plants, the relationship between the structural elements development of panicle productivity and pigment content in the flag leaves of the studied oats varieties was analysed (Table 3).

On average, over three years of research, only six pairs of statistically significant correlations were revealed: the mass ratio of chlorophyll $\mathrm{a} / \mathrm{b}$ was higher in varieties with a large mass of grain per panicle $(\mathrm{r}$ $=0.411)$, per plant $(r=0.485)$ and the mass of 1000 grains $(r=0.418)$.

The same productivity parameters were statistically higher in varieties with a large share of chlorophyll a in the reaction centers of the flag leaf photosystems $(r=0.378 ; 0.429$ and 0.448). In 2015 (normal humidity level), the minimum number of statistically significant pair correlations in the studied set of oats 
varieties between productivity parameters and structural elements of pigment systems was noted: varieties with a greater number of spikelets per panicle were characterized by a lower total chlorophyll a and chlorophyll $\mathrm{b}$ in the flag leaf $(\mathrm{r}=-0.384$ and -0.369$)$, but at the same time, most of chlorophyll a belonged to the reaction centers of photosystems $(r=0.376)$.

Table 3. Average indicators of the pigment complex development in the flag leaf of oat plants in Kirov Oblast, 2015-

\begin{tabular}{|c|c|c|c|c|c|c|c|}
\hline \multicolumn{8}{|c|}{2017} \\
\hline \multirow[t]{2}{*}{ Variety, line } & \multicolumn{4}{|c|}{ Dry weight content $\mathrm{mg} / \mathrm{g}$} & \multicolumn{2}{|c|}{ Mass ratio } & \multirow{2}{*}{$\begin{array}{c}\% \mathrm{Ch} a \text { in } \\
\mathrm{RC}\end{array}$} \\
\hline & Chl $a$ & Chl $b$ & Chl $a+b$ & Car & $\mathrm{Chl} a / b$ & $\mathrm{Chl} / \mathrm{car}$ & \\
\hline $14 \mathrm{~h} 12 \mathrm{o}$ & 12.4 & 7.2 & 19.6 & 3.1 & 1.8 & 6.3 & 32.0 \\
\hline $168 \mathrm{~h} 10$ & 11.5 & 6.4 & 17.9 & 2.9 & 2.1 & 6.0 & 36.7 \\
\hline $1 \mathrm{~h} 07$ & 13.2 & 7.9 & 21.1 & 3.2 & 1.7 & 6.6 & 29.0 \\
\hline $2 \mathrm{~h} 09$ & 11.8 & 6.4 & 18.2 & 3.0 & 2.0 & 6.0 & 36.1 \\
\hline 378h08 & 12.7 & 7.5 & 20.2 & 3.1 & 1.8 & 6.7 & 30.0 \\
\hline $397 \mathrm{~h} 07$ & 11.7 & 6.3 & 18.0 & 3.0 & 2.0 & 5.8 & 37.4 \\
\hline $3 \mathrm{~h} 14$ & 13.0 & 7.0 & 20.0 & 3.3 & 1.9 & 6.0 & 35.7 \\
\hline $629 \mathrm{~h} 09$ & 11.9 & 7.1 & 19.1 & 2.9 & 1.8 & 6.5 & 29.6 \\
\hline $683 \mathrm{~h} 05$ & 14.5 & 9.1 & 23.6 & 3.4 & 1.6 & 7.0 & 25.6 \\
\hline $7 \mathrm{~h} 12 \mathrm{o}$ & 13.7 & 8.3 & 22.0 & 3.3 & 1.7 & 6.7 & 27.9 \\
\hline $857 \mathrm{~h} 05$ & 13.0 & 8.1 & 21.1 & 3.1 & 1.7 & 6.7 & 27.8 \\
\hline SW BETANIA & 10.4 & 5.6 & 16.0 & 2.7 & 1.9 & 6.0 & 36.4 \\
\hline Zvolen & 12.4 & 7.5 & 19.9 & 3.0 & 1.8 & 6.5 & 29.9 \\
\hline Altair & 12.8 & 7.1 & 19.9 & 3.1 & 1.9 & 6.5 & 33.7 \\
\hline Ant & 12.6 & 7.3 & 19.9 & 3.1 & 1.8 & 6.4 & 31.9 \\
\hline Argamak & 12.3 & 7.0 & 19.4 & 3.0 & 1.9 & 6.3 & 32.9 \\
\hline AC-7 & 12.6 & 7.1 & 19.7 & 3.1 & 1.8 & 6.3 & 33.3 \\
\hline Begunok & 12.2 & 6.9 & 19.1 & 3.0 & 1.9 & 6.4 & 33.2 \\
\hline Bulany & 10.1 & 5.5 & 15.5 & 2.7 & 2.1 & 5.6 & 38.2 \\
\hline Vyatsky & 13.0 & 7.9 & 21.0 & 3.1 & 1.7 & 6.7 & 28.3 \\
\hline $\mathrm{I}-4584$ & 15.1 & 9.0 & 24.1 & 3.7 & 1.7 & 6.5 & 29.1 \\
\hline $\mathrm{I}-4592$ & 11.5 & 6.6 & 18.1 & 2.9 & 1.9 & 6.1 & 33.5 \\
\hline $\mathrm{I}-4595$ & 12.7 & 6.9 & 19.6 & 3.3 & 2.0 & 5.7 & 37.2 \\
\hline $\mathrm{I}-4618$ & 13.2 & 7.3 & 20.4 & 3.4 & 2.0 & 5.8 & 36.7 \\
\hline Korifey & 13.1 & 7.8 & 20.9 & 3.2 & 1.8 & 6.5 & 30.8 \\
\hline Lev & 12.3 & 7.1 & 19.4 & 3.1 & 1.8 & 6.2 & 32.3 \\
\hline Lgovsky 72 & 11.5 & 6.8 & 18.3 & 2.9 & 2.0 & 6.2 & 34.6 \\
\hline Pirouette & 12.8 & 7.0 & 19.8 & 3.2 & 2.0 & 6.1 & 36.8 \\
\hline Yakov & 12.4 & 7.1 & 19.5 & 3.1 & 1.9 & 6.3 & 33.3 \\
\hline
\end{tabular}

Note: Chl - chlorophyll, Car - carotenoids, RC - reaction centers of photosystems

The number of pairs of statistically significant correlations increased sharply in the years unfavorable in terms of moisture supply. Thus, with excess moisture in 2017, varieties containing a greater amount of chlorophyll $b$ in the flag leaf had a lower mass of grain per plant $(r=-0.381)$. An increase in the share of chlorophyll $\mathrm{a}$ in the total chlorophyll share was observed in varieties with an increased number of spikelets $(r=0.439)$ and grains $(r=0.398)$ per panicle, higher masses of grain per panicle $(r=0.519)$, of 
plants (0.600) and of 1000 grains (0.370). Besides, these varieties were characterized by a large proportion of chlorophyll a in the reaction centers of photosystems where conversion of stored light energy into primary assimilates takes place. Correlation coefficients with the mentioned panicle productivity parameters were in the range of $0.374 \ldots 0.537$.

In the arid conditions of 2016, statistically significant relationships were observed between the content of pigments in flag leaves and the structural development of reproductive organs: in varieties with higher values of panicle length, panicle mass, number of spikelets per panicle and number of grains per panicle, the content of chlorophyll a $(\mathrm{r}=0.368 ; 0.540 ; 0.455$ and 0.552 , respectively), and of chlorophyll $\mathrm{b}(\mathrm{r}=$ 0.386; 0.604 No. 0.409 and 0.589 , respectively) was increased. The increased content of carotenoids was accompanied by an increase in the number of spikelets and grains per panicle $(r=0.403$ and 0.389$)$. During a drought, however, an increase in panicle mass and the number of grains in it was accompanied by a decrease in the proportion of chlorophyll a in the total pigment pool and in the composition of reaction centers $(\mathrm{r}=-0.531 ;-0.461 ;-0.521$ and -0.465 , respectively).

There can be several reasons for the fact that the number of statistically significant correlations between the productivity structure elements of oat plants and the area of assimilation surface is greater than with the state parameters of the pigment complex of flag leaves.

Firstly, there are differences in variability of the analyzed parameters between the types of oats. The variability of the pigment content under normal humidity was about $10-12 \%$, while for the structural parameters it ranged from 17 to $23 \%$, for the and leaf area from 21 to $28 \%$. A decrease in the variation coefficients in the values of attributes in the dry year of 2016 to $11-18 \%$ led to the manifestation of significant correlations. Probably, the indices of pigment content in the flag leaf are more conservative for the species A. sativa L. than the structural parameters of the generative organs; this may also mean no targeted selection according to the development parameters of the pigment apparatus of the leaves.

Second, the flag leaves pigment complex is relatively more resistant to adverse abiotic growth conditions than the structural components of the reproductive organs. There are indications of similar facts in the scientific literature (Liu et al., 2013; Biswal \& Kohli, 2013). It is also indicated that the stressful conditions of the growth environment (with the exception of light conditions) have a relatively weak effect on the ratio of pigments (Esteban et al., 2015).

Third, despite the fact that using the flag leaves for assessing the pigments content is explained by their maximum content in it during the flowering phase (Kumakov, 1985; Rao, 1997), the flag leaf contributes the biggest (Olszewski et al., 2014 ) but not the only contribution to the synthesis of assimilates. Probably, the content of pigments and their variability in the sub-flag leaf of oat plants needs to be assessed.

Fourth, the experiments performed only evaluated the pigment content in a unit of dry mass of the leaf. This indicator does not take into account the nature of pigments distribution in the total leaf volume and the total pigments content in the entire leaf. Using these parameters in further studies will most likely reveal closer correlations with the level of development of panicle productivity elements.

It can also be assumed that there is currently no purposeful selection of oats to change the state parameters of the pigment apparatus of the leaves. Probably the varieties involved in crossbreeding during programs in different centers have similar parameters of the structural and functional state of the pigment complex. It should be noted that such programs were actively carried out with another cereal crop - wheat (Tarasenko \& Zhivlyuk, 2009; Kiani-Pouya \& Rasouli, 2014). The data on the chlorophyll content in oats leaves are most often used in stress physiology as parameters for assessing the resistance of genotypes to adverse factors of the growth environment (Chauhan et al., 2018; Bai et al., 2018). 


\section{CONCLUSIONS}

Against the background of limited soil resources (sod-podzolic soils), new knowledge was gained on the activity of the photosynthetic structures of oats under the influence of instable agroclimatic factors that limit the vegetation period of plants and their biomass accumulation (total plant productivity), relevant for spring forms of oats and wheat. The total leaf surface area of oats genotypes was most correlated with the mass of grain per plant. The relationship with the number of spikelets per panicle, the mass of grain per panicle and the mass of the panicle itself was somewhat weaker. Samples with a larger leaf area had longer panicles. During a drought, these correlations decreased, and increased under conditions of excessive humidity.

On average, over the years of research, the tested oats genotypes with a larger sub-flag leaf were characterized by a larger panicle, with a large number of spikelets, grains, and grain weight per panicle and plant. Under conditions of normal moisture supply, these patterns intensified, and with the onset of arid conditions, they decreased. Unlike the sub-flag leaf, the correlation of the flag leaf area with the grain mass per panicle and plant increased under stressful conditions of excessive humidity or a drought.

The relationship between the productivity elements development and the chlorophyll content in the flag leaf was strengthened in the years under unfavorable conditions of moisture supply. Thus, excessive moisture increased the proportion of chlorophyll a in the total chlorophyll pool in genotypes with an increased number of spikelets and grains per panicle, higher masses of grain per panicle and plant, and the mass of 1000 grains. Besides, a large proportion of chlorophyll a was characteristic of these varieties in the composition of the reaction centers of photosystems. In arid conditions, the content of chlorophylls a and $b$ increased in genotypes with higher values of panicle length, panicle mass, number of spikelets per panicle and grains per panicle. The increased content of carotenoids was accompanied by an increase in the number of spikelets and grains per panicle. However, under these conditions, an increase in panicle mass and the number of grains in it was accompanied by a decrease in the proportion of chlorophyll a in the total pigment pool and in the composition of reaction centers.

The variability of the pigment content under normal humidity was about $10-12 \%$, while for structural parameters it ranged from 17 to $23 \%$, for leaf area it ranged from 21-28\%. A decrease in the variation coefficients in the values of attributes in dry conditions to $11-18 \%$ led to the manifestation of significant correlations. Probably, the pigment content in the flag leaf is more conservative for the species A. sativa L. than the structural parameters of the generative organs.

\section{REFERENCES}

Al-Tahir, F.M. M. (2014). Flag leaf characteristics and relationship with grain yield and grain protein percentage for three cereals. Journal of Medicinal Plants Studies, 2(5), 1-7.

Bai, J., Yan, W., Wang, Y., Yin, Q., Liu, J., Wight, C., \& Ma, B. (2018). Screening Oat Genotypes for Tolerance to Salinity and Alkalinity. Front. Plant Sci, 9, p. 1302. https://doi.org/10.3389/fpls.2018.01302.

Batalova, G. A. (2013). Oats in the Volga-Vyatka region. Kirov: Orma LLC.

Biswal, A. K., Kohli, A. (2013). Cereal flag leaf adaptations for grain yield under drought. Knowledge status and gaps. Mol Breeding, 31, 749-766. https://doi.org/10.1007/s11032-013-9847-7

Chauhan, A., Rajput, N., Kumar, A., Verma, J. S., \& Chaudhry, A. K.. (2018). Interactive effects of gibberellic acid and salt stress on growth parameters and chlorophyll content in oat cultivars. Journal of Environmental Biology, 39, 
639-646. http://doi.org/10.22438/jeb/39/5/MRN-615

Chen, M. (2014). Chlorophyll Modifications and Their Spectral Extension in Oxygenic Photosynthesis. Annual Review of Biochemistry, 83, 317-340. https://doi.org/10.1146/annurev-biochem-072711-162943

Chen, Y., Liu, L., Guo, Q., Zhu, Z., \& Zhang, L. (2016). Effects of different water management options and fertilizer supply on photosynthesis, fluorescence parameters and water use efficiency of Prunella vulgaris seedlings. Biological Research, 49, 12. https://doi.org/10.1186/s40659-016-0069-4

Croft, H., \& Chen, J. M. (2016). Leaf pigment content In Reference Module in Earth Systems and Environmental Sciences (pp.1-22). Oxford: Elsevier Inc. doi: 10.1016/B978-0-12-409548-9.10547-0

Esteban, R., Barrutia, O., Artetxe, U., Fernández-Marín, B., Hernández, A., \& García-Plazaola, J. I. (2015). Internal and external factors affecting photosynthetic pigment composition in plants: A meta-analytical approach. New Phytologist, 206, 268-280. https://doi.org/10.1111/nph.13186.

Hisir, Y., Kara, R., \& Dokvyucu, T. (2012). Evaluation of oat (Avena sativa L.) genotypes for grain yield and physiological traits. Zemdirbyste Agric, 99, 55-60.

Kakad, R. E., Sapkal, D. R., Thakare, G. K., \& Iratkar, A. G. (2017). Study of morphological and genetical variabilities for improving forage production in oat. Internat. J. Plant Sci, 12(1), 1-14. https://doi.org/10.15740/HAS/IJPS/12.1/1-14

Khan, A., Pan, X., Najeeb, U., Tan, D.K.Y., Fahad, S., Zahoor, R., \& Luo, H. (2018). Coping with drought: stress and adaptive mechanisms, and management through cultural and molecular alternatives in cotton as vital constituents for plant stress resilience and fitness. Biological Research, 51, 47. https://doi.org/10.1186/s40659-018-0198-Z

Kiani-Pouya, A., \& Rasouli, F. (2014). The potential of leaf chlorophyll content to screen bread-wheat genotypes in saline condition. Photosynthetica, 52(2), 288-300. https://doi.org/10.1007/s11099-014-0033-x

Kumakov, V. A. (1985). Physiological substantiation of models of wheat varieties. Moscow: Agropromizdat.

Lichtenthaler, H. K., \& Buschmann, C. (2001). Chlorophylls and carotenoids: measurement and characterization by $U V$-VIS spectroscopy. Current protocols in food analytical chemistry. F. 4.3.1-F. 4.3.8.

Liu, W., Yu, K., He, T., Li, F., Zhang, D., \& Liu, J. (2013). The Low Temperature Induced Physiological Responses of Avena nuda L., a Cold-Tolerant Plant Species. The Scientific World Journal, Article ID 658793. https://doi.org/10.1155/2013/658793

Methodology of state testing of crops varieties (1985). Moscow.

Mistra, A. N. (1986). Effect of temperature on senescing rice leaves. I. Photoelectron transport activity of chloroplast. Plant Sci, 46, 1-4. https://doi.org/10.1016/0168-9452(86)90123-8.

Mushtaq, A., Gul, Z., Razvi, S. M., Dar, Z. A., Khan, M. H., \& Ganie, S. A. (2013). Combining ability study in oat (Avena sativa L.) for physiological, quality traits, forage and grain yield. African Journal of Agricultural Research, 8(43), 5245-5250. https://doi.org/10.5897/AJAR2013.7751

Nava, I. C., Pacheco, M. T., \& Federizzi, L. C. (2016). URS Altva - a new oat cultvar with high agronomic 
performance. Crop Breeding and Applied Biotechnology, 16, 254-260. https://doi.org/10.1590/1984$\underline{70332016 \mathrm{v} 16 \mathrm{n} 3 \mathrm{c} 39}$

Olszewski, J., Makowska, M., Pszczołkowska, A., Okorski, A., \& Bieniaszewski, T. (2014).The effect of nitrogen fertilization on flag leaf and ear photosynthesis and grain yield of spring wheat. Plant Soil Environ, 60(12), 531-536. http://www.agriculturejournals.cz/publicFiles/138173.pdf

Rahman, M. A., Haque, M. E., Sikdar, B., Islam, M. A., \& Matin, M. N. (2014). Correlation analysis of flag leaf with yield in several rice cultivars. J. Life Earth Sci, 8, 49-54. https://doi.org/10.3329/jles.v8i0.20139

Rao, S. D. (1997). Flag leaf a selection criterion for exploiting potential yields in rice. Indian J. Plant Physiol, 25(3), 265-268.

Santosh, K. (2011). Yield response of uniculm wheat (Triticum aestivum L.) to early and late application of nitrogen: flag leaf development and senescence. Journal of agricultural science, 3(1), 170-182. https://doi.org/10.5539/jas.v3n1p170.

Schennikova, I. N. (2015). Models of spring barley varieties for the conditions of the Volga-Vyatka region. Agricultural science of the Euro-North-East, 6(49), 9-13.

Sytar, O., Bruckova, K., Hunkova E., Zivcak M., Konate K., and Brestic M. (2015). The application of multiplex fluorimetric sensor for the analysis of flavonoids content in the medicinal herbs family Asteraceae, Lamiaceae, Rosaceae. Biological Research, 48, 5. https://doi.org/10.1186/0717-6287-48-5

Tarasenko, S., Zhivlyuk, E. (2009). Pigment composition of varieties of soft winter wheat. Science and Innovations, $7(77), 25-28$.

Verma, D., Gontia, A. S., Jha, A., \& Deshmukh, A. (2016.). Study of leaf area index and leaf area duration of growth analytical parameters in wheat, barley, and oat. International journal of Agriculture, Environment and Biotechnology, 9(5), 837-831. https://doi.org/10.5958/2230-732X.2016.00106.6

Xie, X. J., Shen, S. H. H., Li, Y. X., Zhao, X. Y., Li, B. B., \& Xu, D. F. (2011). Effect of photosynthesis characteristics and dry matter accumulation of rice under high temperature heading stage. Afr. J. Agric. Res, 6(7), 1931- 1940. https://doi.org/10.5897/AJAR11.087

\section{SEMBLANCE OF THE AUTHORS}

Galina A. Batalova: She is a Full Doctor of Agricultural Sciences, Professor, Member of the Russian Academy of Sciences.

Evgeny M. Lisitsyn: He is a Doctor of Biological Sciences. 